\title{
MOTIVATION OF FOREIGNERS TO LEARN THE LITHUANIAN LANGUAGE
}

\author{
Jakub Kubś, Aleksandra Michałowska-Kubś \\ University of Wrocław
}

\begin{abstract}
The article discusses the motivation of adults coming to Lithuania to learn Lithuanian as a foreign language ${ }^{1}$. The motivational background for learning "small" languages will be discussed. Lithuanian, spoken by approximately 3.5 million people worldwide, is an example of a less popular choice for foreign language learners. However, reindependence in 1991 and joining the European Union in 2004 created new opportunities for teaching Lithuanian as a foreign language. In this paper we wanted to examine the motivational factors driving foreign adults to come to Lithuania to learn its language. The theoretical framework was based on the motivation theories of Gardner and Lambert (1972) and Deci and Ryan (1985). The main tool used for the purpose of research was the Foreign Language Learning Motivation Questionnaire (Gonzales, Lopez 2016). We conducted quantitative research on a representative sample of 114 respondents who participated in different language courses in Lithuania. The results show that learning Lithuanian is strongly connected with internal and integrative motivation, rather than external and instrumental, while the autotelic value of Lithuanian language was also highly rated by the students. This confirms that learning "small" languages needs special motivation and instrumental factor plays a lesser role. The article ends with a discussion of the results within a wider context.
\end{abstract}

Keywords: motivation, Lithuanian, "small" language, foreign language, language learning

\footnotetext{
This article was written as part of the project "Lithuanian Academic Scheme for International Cooperation in Baltic Studies" (2020), carried out at the Vytautas Magnus University under the supervision of Dr. Laura Kamandulytè-Merfeldienè and Dr. Vilma Leonavičienè.
} 


\section{Introduction}

This paper examines the motivational factors for adult foreigners learning the Lithuanian language in Lithuania. Motivation is the term commonly used in everyday practice. It is generally believed that motivated individual will better strive for success than unmotivated ones. This factor plays a significant role especially in the field of education (Keller 1983), as: "Motivation is a key to learning in general" (Brown 2007: 168). Various studies also confirmed its magnitude in the area of foreign language learning (Gardner, Lambert 1972; Crookes, Schmidt 1991; Oxford, Ehrman 1992; Dörnyei 1990, 1994, 1998; Yu, Watkins 2008), sometimes describing motivation as the single most influential factor in learning a new language (Gardner 1985).

Considering the above, motivation has always been a subject of linguistic interest, both from a theoretical and practical perspective. However, it is worth noting that the attention of researchers has usually focused on world languages (Saheb 2014; Alizadeh 2016; Al-Ta'ani 2018). Under the term world languages, we understand languages intentionally learned as a second language by numerous people in different countries, and commonly used in international, global relationships. At this point it is worth to distinguish second (L2) and foreign language (FL) (Laizāne 2018). In a narrow sense, second language can be defined as a language that: "Plays a major role in a particular country or region though it may not be the first language of many people who use it" (Richards, Schmidt 2010: 514). The most frequently mentioned are English, French, German, and Spanish. On the other hand, the majority of foreign languages do not fulfill such conditions and their use is restricted mainly to one country. As Ushioda and Dörnyei (2017) noted, while research on motivation to learn foreign languages is increasing, $70 \%$ of the publications in the 2005-2014 period concerned learning English. Thus, the group of less widely spoken or "small" languages has acquired limited scholarly attention. 
In our study we wanted to explore this using the example of the Lithuanian language. Our research question was: "What motivates adult foreigners to learn the Lithuanian language, as a foreign language, in Lithuania?" Our goal was to examine the individual motivation of participants and investigate whether there is a shared specific motivation to learn Lithuanian among participants. We also wanted to place our results in the theoretical framework of research on motivation (Gardner, Lambert 1972; Deci, Ryan 1985). For this purpose, we used the Foreign Language Learning Motivation Questionnaire (Gonzales, Lopez 2016). Referring to the existing literature on the motivation to learn smaller languages (Dąbrowska 2008; Stanulewicz 2008; Cobel-Tokarska 2014; Kowal 2019; Klaas-Lang, Reile 2019), we made a hypothesis that in case of Lithuanian learners' motivation is integrating and internal.

The study was conducted on a representative group of 114 foreigners. Historical ethnic minorities (Polish, Russian, and others) were not included in this study as for the vast majority of them Lithuanian is the second language. Both quantitative and qualitative statistics were used to summarize the results. It should be mentioned that, to the authors' best knowledge, there is no prior research stricte on the motivation to learn Lithuanian as a foreign language. Scholars asked similar questions, but the scope of their interest was restricted to general observations of motivation (Zygmantas 2011), of language acquisition (Ramonienè 2006; Ramonaite 2019) or focused on pupils coming from national minorities (Poles, Russians) and learning Lithuanian language as a second language (Geben, Ramoniene 2015; Vilkienè et al. 2019). There is also another group of research dedicated to specific linguistic problems among adult newcomers (Buivydiené, Žukienè 2006; Zakarauskaite 2006; Dabašinskienè, Čubajevaitè 2009; Ramonaitė 2015, 2017a, 2017b). Some similar studies on motivation have been conducted in the context of the Estonian language (Nelis, Miljan 2016; KlaasLang, Reile 2019) and, to a lesser degree, Latvian (Šalme 2011; Laizāne 2017). 
This paper firstly outlines the sociolinguistic context of Lithuania along with a short discussion of its characteristic features. Thereafter, the development of motivational theories in one's linguistic background is discussed. The procedure and results of the study are subsequently summarized. The article concludes with a brief discussion of the results within a broader context.

\section{Sociolinguistic situation in Lithuania}

In order to better understand the specificity of the Lithuanian language, it is necessary to outline the characteristic circumstances in which its contemporary sociolinguistic situation was shaped. Lithuania along with Latvia and Estonia form a non-formal geopolitical grouping called the "Baltic states" (or "Baltics"). Today, Lithuanian and Latvian are the only living languages belonging to the Baltic sub-family of the Indo-European language family (Estonian language belongs to a different family - Uralic languages). Lithuanian is spoken by approximately three million people in Lithuania and by an additional half of million elsewhere in the world ${ }^{2}$. Lithuania is a relatively small country, occupying $31^{\text {st }}$ place out of 48 European countries in terms of population ${ }^{3}$.

In order to better understand the situation of the Lithuanian language, it is necessary to look at the historical background of the nation. Over the centuries, the development of the Lithuanian language was adversely affected by political and socio-cultural factors. Long periods of foreign rule led to the imposition of imperial languages - Polish, German and twice Russian - and the restriction of the use of Lithuanian. From the mid 16th century onwards, when the Polish-Lithuanian Commonwealth emerged, Lithuania was a subject of cultural and linguistic Polonization, while in the 19th

https://www.vle.lt/Straipsnis/lietuviu-kalba-118006 (22.09.2020).

https://www.worldometers.info/population/countries-in-europe-by-population/ (22.09.2020). 
century with the start of Russia occupation, the country was subject to intensified Russification. During the first period of independence (1918-40), the use of Lithuanian rose (with the exception of in Polish-occupied Vilnius). However, the Nazi occupation in 1941-44 meant the imposition of the German language. Incorporation of Lithuania into the Soviet Union after the Second World War saw the return of linguistic Russification. After regaining independence in 1991, Lithuania and the other two Baltic States worked on the reconstruction of their own life, identity and language (Hogan-Brun et al. 2008).

Paradoxically, the limitations placed on the use of the Lithuanian language over the centuries contributed to its conservation in a relatively unaltered form. As modern scholars acknowledge, it is the still existent language closest to Proto-Indo-European, the ancestral tongue from which all the Indo-European languages evolved (Hogan-Brun et al. 2005). At the same time, linguists emphasize the unique character of the Lithuanian language as the one of the most ancient of the living Indo-European languages (Klimas 1969).

Nowadays, Lithuanian occupies the dominant position within the state and the majority of its residents consider it to be their first language. However, due to the complex history, the Baltic states are largely ethnically diverse. In Lithuania, there are two significant ethnic minorities: Poles (6.6\%) and Russians (5.8\%) ${ }^{4}$. Efficient acculturation through teaching of the Lithuanian language as a second language is a goal of the linguistic politics of the state (Vihalemm, Hogan-Brun 2013).

On the other hand, access to the European Union in 2004 increased international exchange, hence Lithuanian has been taught as a foreign language to a greater number of persons (Buivydiené, Žukienè 2006). The value of learning foreign languages and multilingualism is set out in European Union policy: "Languages unite people, render other countries and their cultures accessible, and

4 Data for 2011: https://lrkm.lrv.lt/en/activities/national-minorities (22.09.2020). 
strengthen intercultural understanding. Foreign language skills play a vital role in enhancing employability and mobility. Multilingualism also improves the competitiveness of the EU economy"

Member countries adapted teaching national languages as a part of self-promotion. It is of particular importance for smaller states, as: "Exporting the idea of 'small is beautiful' can stimulate consumer demand for something that seems authentic and rare, and benefit from it" (Hogan-Brun 2017: 123). Promotion of Lithuanian as one of the oldest Indo-European languages gave it a unique character, which may provide special motivation for learning it (CobelTokarska 2014).

\section{Theoretical approaches to motivational orientation}

Although there is no unified definition of motivation (Kleinginna, Kleinginna 1981), according to Marriam-Webster Dictionary, a motive could be described as: "something (such as a need or desire)

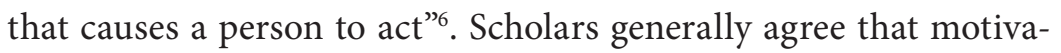
tion is: "an internal state that arouses, directs and maintains behavior" (Woolfolk 2013: 431). Researchers have proposed a number of attributes to characterize a motivated individual, such as one who is: "goal directed, expends effort, is persistent, is attentive, has desires, exhibits positive effect, is aroused, has expectancies, demonstrates self-confidence (self-efficacy), and has reasons (motives)" (Gardner 2006: 2).

Motivation provides the primary impetus to: "sustain [a] long and often tedious learning process” (Dörnyei, Ushioda 2009: 25), such as learning a foreign language. As it is stressed, lack of motivation makes achieving long-term goals a difficult task, even for individuals with exceptional abilities and excellent instruction (Dörnyei 1998). Motivation is also important as it makes both "teaching

\footnotetext{
5 https://ec.europa.eu/education/policies/multilingualism/about-multilingualismpolicy_en (22.09.2020).

6 https://www.merriam-webster.com/dictionary/motive (22.09.2020).
} 
and learning immeasurably easier and more pleasant" (Ur 1996: 274). Since Chomsky (1988: 181) noted that the $99 \%$ of the role of a teacher is arousing students' interest in the subject, motivation can be regarded as the core of language teaching.

Different theoretical frameworks have been developed to profile motivation of foreign language learners. In this context, Gardner and Lambert's (1959) approach is often considered as pioneering, and was later developed into a socio-educational model. According to it, there are two orientations supporting motivation to learn a foreign language: integrative and instrumental. The former means positive attitude toward a foreign culture and desire to participate in a given group (but not necessarily willingness or desire to actually become a member). On the other hand, the latter refers to learning a language with a goal of obtaining social or economic rewards. Gardner and Lambert (1972) claimed that integrative motivation plays a greater role in learning a foreign language. This orientation is often combined with intrinsic motivation, as stated Szałek: "A student masters a foreign language because of his fascination with cultural patterns developed by the community that uses the language, and thus for their own pleasure and broadening their horizons" (1992: 78).

However, as later studies shown, it is possible to achieve very high levels of proficiency even for highly ethnocentric learners, despite lacking the desire to integrate into the culture of a nation that uses the language being learned (Gonzales 2010). Studies have not clearly indicated which factor gives better results in language advancement tests (Lankiewicz 2010: 113). It should also be noted that instrumental and integrative motivations are not necessarily opposite to each other and learners can possess both types. Scholars highlight that success can be achieved regardless of whether instrumental or integrative motivation prevails, as long as motivation in general is sufficiently strong (Clément et al. 1994).

In the mid-1980s, Deci and Ryan (1985) proposed a different model of understanding motivation, later developed into selfdetermination theory (2000). Their research concentrated on the 
dichotomy of intrinsic and extrinsic motivation. The former factor refers to motivation that comes from the learner themselves and is related to their identity, well-being and emotions, where learning becomes a goal in itself. On the other hand, the source of extrinsic motivation is external and is linked with a carrot and stick approach: possibility of receiving a reward ("a carrot") or avoiding a penalty ("a stick"). Deci and Ryan noted that: "intrinsically motivated learning is superior to extrinsically motivated learning” (1985: 248). Later studies confirmed that internal orientation brings greater longterm benefits than external motivation, which, however, remains an important aspect in the didactic process (Arnold, Brown 2005: 14). Research shows that intrinsic motivation is particularly important in the field of foreign language learning (Kowal 2019).

Gonzales synthesized various motivation models of learning a foreign language. Referring to the integrating/instrumental and external/internal motivation theories, he developed the Foreign Language Learning Motivation Questionnaire (FLLMQ; Gonzales 2006) - later revised (Gonzales, Lopez 2016, 2017). Currently, this instrument consists of 40 Likert-type items that measure six motivational orientations in foreign language learning. In our study we used the modified version of FLLMQ.

\section{Methods and research data}

\section{I. MEASURES}

The present study consisted of a three-part questionnaire. In the first part, participants were asked to describe their motivation for studying Lithuanian. There were also closed and semi-closed questions about specific courses taken in Lithuania and details about these.

The second instrument was based on the FLLMQ (alpha coefficient reliability index of .941). The Likert scale was used to quantify the answers (Likert 1932) - participants were required to indicate whether they agreed or disagreed with each statement on a scale of 1 (strongly disagreed) to 6 (strongly agreed). 
Six factors were measured: (F1) desire for career and economic enhancement; (F2) desire to become a global citizen; (F3) desire to communicate and affiliate with foreigners; (F4) desire for self-satisfaction; (F5) self-efficacy; and (F6) desire to be integrated into other cultures. Factor (F1) indicates an instrumental motivation. Factors (F2), (F3), and (F6) indicate integrative motivation. Factors (F4) and (F5) indicate intrinsic motivation.

In this part we also asked the participants about self-perceived ability to learn a language (writing, reading, listening, speaking), and their opinions about learning Lithuanian (is it fun, satisfying, easy), both on a ten-point scale (Gonzales, Lopez 2017).

The third instrument was a metric, which included information like age, gender, nationality, occupation, duration of learning Lithuanian, and proficiency. Participants were informed about the purpose of the study. The study was anonymous.

\subsection{PROCEDURE}

The research was conducted using an online tool (Google Forms). The questionnaire was sent to participants via e-mail by responsible academic staff in different major Lithuanian universities (Vytautas Magnus University in Kaunas and branch in Vilnius, and Klaipeda University). The research was conducted over a month and a half (6 April 2020-17 May 2020). Statistical analyzes were performed using the Statistical Package for the Social Sciences (SPSS Inc., Chicago, IL), ver. 24 .

\subsection{PARTICIPANTS}

In total, 114 respondents took part in the study. The gender distribution was 67 females (58.8\%) and 47 males (41.2\%). The participants originated from 33 countries, which indicates widespread interest in learning Lithuanian in many states around the world. The citizens of seven countries (respectively: Ukraine, Poland, 
Russia, Indonesia, Georgia, Latvia and Germany) covered a large majority (61.4\%).

The age of the participants was between 18 and 69 years old, with a large minority (47.4\%) between 18 and 25 years old. More than half of participants were students (60.5\%), which shows the popularity of academic programs for learning the Lithuanian language. The rest declared various professional activities, e.g. university lecturer, language teacher, nurse, medic, architect, etc. Almost half of participants (43.8\%) studied courses connected with linguistics or Baltic languages. In these cases, it is predictable that people studying these fields of study were interested in deepening their knowledge from within Lithuania. On the other hand, the educational background of over half of the respondents was not explicitly related to Baltic languages or the Baltic countries.

Participants were also asked about the number of known foreign languages. Almost all respondents (90.4\%) declared knowledge of more than one foreign language: $26.3 \%$ knew two foreign languages; $37.7 \%$ - three; and $26.4 \%$ - four or more. A variety of foreign languages was mentioned, for instance Arabic, Chinese, Croatian, Danish, English, German, Korean, Lithuanian, Russian and Spanish. This shows that the participants are generally interested in learning foreign languages and the vast majority knows at least one foreign language before starting to learn Lithuanian.

Most of the participants took part in the Summer or Winter Courses of the Lithuanian Language and Culture organized in Vilnius, Kaunas or Klaipèda (86\%). Others learned Lithuanian during their Baltic Studies or Erasmus+ Program. Some respondents participated in more than one type of program. The duration spent learning Lithuanian language differed significantly among respondents: from one month up to seven years; however, a large majority $(73.6 \%)$ had been learning the language for less than half a year. 


\section{Results}

\section{I. PARTICIPANTS' IMPRESSIONS, LEVEL OF PROFICIENCY} AND PLANS CONNECTED WITH LITHUANIA(N)

Apart from motivation, we also wanted to understand the participants' impressions of the courses and language. Firstly, we asked, whether the stay in Lithuania had helped them to achieve their goals. The vast majority agreed (86.8\%). The participants were also asked an open question about what they appreciated the most during the language course in Lithuania. The answers were divided into three groups. The largest group (56.1\%) focused on the organizational and academic aspects of the course ("I highly appreciated the lecturer and program director, as they [warmly welcomed me as an] overseas student and [the] other [students] are also friendly. It showed that the program respects the diversity fully", "Excellent organization of the educational process, modern methods of language teaching; fascinating cultural program (...)", "Atmosphere in academy"). The second group (25.4\%) valued above all the cultural aspect ("We weren't only studying language but also culture and traditions", "The welcoming of Lithuanians, who are so warm to people who study their native language", "Extreme warm-heartedness, wisdom, dignity and modesty of the Lithuanians", "Everyday contact with natives"). The third group (17.5\%) highlighted socializing with course colleagues and other people met during the stay ("Participation in Lithuanian language and culture courses provided me the possibility to meet in Lithuania many interesting people from other countries, make some new friends and to establish some new contacts with foreign colleagues", "Exchange of cultures", "Meeting so many nice people").

We also asked the participants about their level of Lithuanian language proficiency before coming to Lithuania. Almost half of respondents (45.6\%) had not studied the language before, while others had very limited (29.8\%) or basic (15.8\%) level of proficiency. Only a minority $(8.8 \%)$ declared prior intermediate or advanced 
level. After the course, more than half of all participants (50.9\%) achieved at least intermediate level $(\mathrm{B} 1=23.7 \%, \mathrm{~B} 2=18.4 \%, \mathrm{C} 1=8.8 \%)$.

An important piece of information given by respondents was that the vast majority of them $(86.8 \%)$ want to continue learning Lithuanian. More than one third of participants (34.2\%) declared that they aimed to acquire intermediate level, while over the half (56.1\%) - advanced or fully proficient. This shows that the majority of respondents are motivated to develop their knowledge of Lithuanian.

Asked about the plans for continuing to live in Lithuania, over a quarter of respondents showed a willingness to do so (27.2\%), while more than half of participants (56.1\%) were undecided. Only a minority (16.7\%) categorically rejected this option.

\subsection{INDIVIDUAL MOTIVATION FOR STUDYING LITHUANIAN}

The principal goal of our research was to discover what motivates people from various countries to learn Lithuanian. First of all, we wanted participants to express their motivation in their own words. Therefore, we asked an open question: "If you were to say in few words what your general motivation to study Lithuanian was, what would it be?”. In analyzing the responses, we differentiated five groups.

For the largest part of participants (31.6\%), the most important motivation was the Lithuanian language itself, its special character as the oldest surviving Indo-European language ("Lithuanian is one of the oldest languages in the world. The most interesting fact about Lithuanian for me personally because its history which makes this language similar with ancient javanese [sic.] language in Indonesia called "sanskrit" [sic.] and that['s] what makes me curious") combined with a desire to communicate with Lithuanians ("Have a casual conversation with Lithuanian[s]"). The often-emphasized exceptional status of the Lithuanian language corresponds to the thesis about the need for special motivation to learn a "small" language. 
The second largest group (21.1\%) highlighted general curiosity towards studying in a different country, getting to know Lithuanian culture, new people, etc. ("To explore a new wonderful language and culture", "Exploring [a] new environment and culture that have a very unique language").

A relatively large group of participants (19.3\%) declared that they needed knowledge of Lithuanian for their studies, research or work ("I live, work and study in Lithuania"). Thus, this group was motivated by rather instrumental motivation.

The second to last group (15.8\%) stated that their main motivators were private associations with Lithuanians, like family roots, relatives speaking Lithuanian, friends and partners ("My grandfather is Lithuanian so I've always felt both desire and duty to be able to speak Lithuanian", "I have family in Lithuania so I want to improve my Lithuanian language because of them").

The minority of respondents (12.3\%) expressed that their main motivation was simply taking advantage of the opportunity and desire to have a new experience ("There was a course in my uni and I decided to take it just because I had free time, then started to like the language a lot and couldn't stop", "I was interested in trying something new and changing my life").

Additional information we received from participants concerned their motivations to study the Lithuanian language in Lithuania in particular. We grouped answers into three main categories. More than half of participants (55\%) were driven by a desire to participate in an attractive activity, program which was an opportunity to spend time in Lithuania and learn its language and culture ("My Lithuanian professor suggested that I apply for the Lithuanian Language and Culture Summer Course and I thought it was a great idea because it was a good chance to practice the language and just have fun :)", "My teacher recommended me to apply for Summer courses in Lithuania. For me, it was important that it was free", "(...) it's quite interesting to [come] across different kind of networking, cultural, and languages at the same time. And I should say Lithuania is not [a] 
familiar place for us Asian[s]. So, it would be [an] amazing journey to explore"). This result strongly indicates an integrative motivation. The second group was motivated by personal/professional reasons (23\%), which is in line with the answers to the previous question ("I moved to Lithuania for personal, work-related reasons", "Mano žmona iš Lietuvos" ["My wife from Lithuania"], "I had an old desire to see my father's fatherland"). The last group (22\%) emphasized crucial value of immersion into the language of native speakers ("To get the best experience. There is nothing [better] than learning a language in a country [whose] people speak that language", "I wanted a chance to actually apply the language I learned in my country in an immersive environment").

In the next question participants were directly asked to rate on scale of 1 ("not important") to 10 ("very important") how important for them were types of motivation expressed by the following statements: "To enhance my chances on the job market" (instrumental factor), "To visit Lithuania and know better Lithuanian culture" (integrative factor), "To get other benefits from taking part in the course/ studies" (extrinsic factor), "To develop myself in new field and try something new, to gain experience" (intrinsic factor). Answers were in line with the aforementioned assumptions: intrinsic motivation concerning self-development and experiencing newness obtained the highest result $(\mathrm{M}=8.76, \mathrm{SD}=1.8)$. The desire to integrate with Lithuanians was also a strong factor $(\mathrm{M}=7.97, \mathrm{SD}=2.4)$; same as extrinsic motivation and gaining other benefits $(\mathrm{M}=7.43, \mathrm{SD}=2.8)$. The sentence least agreed with concerned learning the language because of

Table I. Mean and SD of Instrumental/ Integrative \& Extrinsic/ Intrinsic Motivation

\begin{tabular}{|l|c|c|c|c|}
\hline Factors & Minimum & Maximum & Mean & SD \\
\hline I: Instrumental Motivation & $\mathrm{I}$ & 10 & 5.82 & 3.28 \\
\hline 2: Integrative Motivation & $\mathrm{I}$ & 10 & 7.97 & 2.43 \\
\hline 3: Extrinsic Motivation & $\mathrm{I}$ & 10 & 7.34 & 2.79 \\
\hline 4: Intrinsic Motivation & 3 & 10 & 8.76 & 1.8 \\
\hline
\end{tabular}

Note: higher mean scores indicated higher endorsement of the items 
professional benefits $(\mathrm{M}=5.82, \mathrm{SD}=3.3)$, although the relatively high standard deviation indicates more strongly biased answers.

In our study we also wanted to examine the role of external factors, such as financial support or scholarship for participants. A majority (67.5\%) declared that they had received scholarship. This group was further asked to determine how decisive this factor was for them (with "1" as "not important" and "6" as "very important"). The results showed that financial support was a very important factor for the respondents who obtained it $(\mathrm{M}=5.3, \mathrm{SD}=1.14)$. It indicates that extrinsic motivation played an important role for that group.

In the next part, we wanted to examine the motivation of the participants in more detail. For this we used the FLLMQ. As the results showed, the most primary motivational orientations for learning Lithuanian were: (F2) desire to become a global citizen $(\mathrm{M}=5.2, \mathrm{SD}=0.91),(\mathrm{F} 3)$ desire to communicate and affiliate with foreigners $(M=5.0, S D=0.72)$, ( $F 6)$ desire to be integrated with other cultures $(\mathrm{M}=4.7, \mathrm{SD}=0.85)$, and (F5) self-efficacy $(\mathrm{M}=4.6, \mathrm{SD}=1.02)$. The two lowest factors were: (F4) desire for self-satisfaction $(\mathrm{M}=3.9$, $\mathrm{SD}=1.10)$ and (F1) desire for career and economic enhancement $(\mathrm{M}=3.6, \mathrm{SD}=1.49)$. These trends overall indicate that respondents are less motivated by the chance of getting a job connected with Lithuanian or driven by general a desire for self-satisfaction unconnected to the cultural or linguistic aspect.

Table 2. Mean, SD, Skewness, and Kurtosis of FLLMQ

\begin{tabular}{|l|c|c|c|c|c|c|c|}
\hline FLLMQ Factors & $\begin{array}{c}\text { No. of } \\
\text { Questions }\end{array}$ & Min. & Max. & Mean & SD & $\begin{array}{c}\text { Skew- } \\
\text { ness }\end{array}$ & Kurtosis \\
\hline FI: Career enhancement & 8 & $\mathrm{I}$ & 6 & 3.60 & 1.49 & -0.03 & -0.92 \\
\hline F2: Global citizenship & 7 & 2 & 6 & 5.17 & 0.92 & -1.2 & 0.99 \\
\hline $\begin{array}{l}\text { F3: Affiliation with } \\
\text { foreigners }\end{array}$ & 6 & 2 & 6 & 5.03 & 0.73 & -0.83 & 1.07 \\
\hline F4: Self-satisfaction & 6 & $\mathrm{I}$ & 6 & 3.93 & 1.1 & -0.3 & -0.14 \\
\hline F5: Self-efficacy & 6 & $\mathrm{I}$ & 6 & 4.64 & 1.02 & $-0.7 \mathrm{I}$ & 0.15 \\
\hline F6: Cultural integration & 5 & $\mathrm{I}$ & 6 & $4.7 \mathrm{I}$ & 0.85 & -0.76 & 1.0 \\
\hline
\end{tabular}

Note: higher mean scores indicated higher endorsement of the items 
Exploration of the participants' motivation indicates that the least important motivator for studying Lithuanian was instrumental motivation in favor of the integrative and intrinsic, while the extrinsic factor was also significant. It should be stressed that these tendencies were revealed even though the study was conducted on a diverse group (e.g. age, country of origin, student status, profession).

\subsection{DIFFERENTIATION OF MOTIVATIONAL ORIENTATIONS}

Various factors were tested in order to examine the differences of motivational orientation among the participants. Because the assumptions of the normal distribution were not maintained, we conducted non-parametric tests. This was associated with the use of a six-point Likert scale in the FLLMQ and the extreme responses on the scale.

The first observed differentiating factor for the students' motivation was desire to live in Lithuania. Participants who intended to continue to live in the country had higher scores in three motivation factors then people who did not plan or were undecided: (F6) desire to integrate with other cultures $(\mathrm{K}=23.72, \mathrm{p}<.001)$, (F3) desire to communicate and affiliate with foreigners $(\mathrm{K}=8.38, \mathrm{p}<.05)$ and $(\mathrm{F} 1)$ desire for career and economic enhancement $(K=15.57, \mathrm{p}<.001)$. In the case of participants who saw their future being connected with Lithuania, integrative and instrumental motivation played a greater role, which is consistent with other studies (Klaas-Lang, Reile 2019).

We also investigated participants' motivation considering whether or not their country of origin bordered Lithuania. We wanted to examine this factor, because the professional aspect of motivation is frequently enhanced by proximity of the learner's country of origin, which is conducive to close trade, investment, etc. Almost half of the participants who took part in the study (44\%) were from neighboring countries (Latvia, Belarus, Poland and Russian Federation). The results show that those respondents were significantly more focused on (F1) desire for career and economic 
enhancement $(Z=-2.16, p<.05)$ and $(F 4)$ self-satisfaction $(Z=-2.42$, $\mathrm{p}<.05)$. Thus, the research confirmed, amongst these participants, the existence of the desire for use of the Lithuanian language in a professional capacity.

By taking a broader perspective, we also compared participants from countries within the European Union (EU) and those from countries outside the EU. Statistically significant differences were observed. In almost all motivational factors, Lithuanian learners coming from non-EU states achieved higher averages: (F1) desire for career and economic enhancement $(\mathrm{Z}=-2.16, \mathrm{p}<.05)$, (F3) desire to communicate and affiliate with foreigners $(Z=-2.60$, $\mathrm{p}<.01)$, (F4) desire for self-satisfaction $(\mathrm{Z}=-3.39, \mathrm{p}=.001)$, (F5) self-efficacy $(Z=-2.37, \mathrm{p}<.05)$ and $(\mathrm{F} 6)$ desire to integrate into other cultures $(Z=-2.37, \mathrm{p}=.01)$. Furthermore, in the remaining factor: (F2) desire to become global citizen $(\mathrm{Z}=-1.71, \mathrm{p}=.088)$ this tendency was noted. It can be assumed that there are several factors influencing the above results. Firstly, for participants from countries outside the $\mathrm{EU}$, travelling to Lithuania is more difficult for logistical reasons (visa, distance, etc.), which may indicate greater self-determination of those learners that do manage to visit. On the other hand, for some of these participants, coming to Lithuania and learning its language may be an exotic experience, especially in the case of those from countries further afield, which may increase one's curiosity and enhance the experience. It is also worth noting that for some students, arrival in an EU country, such as Lithuania, and participation in language courses, is an introduction to further exchange programs, studies, and, in the longer term, a career opportunity. However, on this point, it is recommended that in-depth and more detailed research on students from distant countries be carried out.

Differences were also observed depending on the level of Lithuanian the participants desired to acquire via their learning. Learners who declared desire to obtain fully proficient skill were more intrinsically (desire for self-satisfaction, $\mathrm{K}=12.2, \mathrm{p}<.01$ ), as well as 
instrumentally motivated (desire for career and economic enhancement, $\mathrm{K}=10.36, \mathrm{p}=.01$ ) in comparison to those willing to obtain intermediate level.

Contrary to Gonzales (2010), our study did not indicate any statistically significant differences in motivation between men and women. Likewise, no significant differences were observed between participants taking into account number of known foreign languages. Some factors could not be investigated due to the insufficient number of participants in the subgroups, e.g. differences due to having Lithuanian heritage (6 people) or differences in the self-assessment of linguistic abilities of people using the closest related language Latvians (7 people). These questions require further research.

\subsection{ATTITUDES TOWARDS LEARNING, SELF-REPORTED LANGUAGE SKILLS AND THEIR RELATIONSHIP BETWEEN MOTIVATION}

In our study, we wanted to examine learners' attitude towards the process of learning Lithuanian language. The participants were asked to rate their learning of Lithuanian in terms of three factors (ease, fun, satisfaction) on a scale of 1 (strongly disagree) to 10 (strongly agree). According to the respondents, learning Lithuanian is much more satisfying $(\mathrm{M}=7.9, \mathrm{SD}=1.83)$ and fun $(\mathrm{M}=7.5, \mathrm{SD}=2.09)$ than easy $(\mathrm{M}=4.6, \mathrm{SD}=2.33)$.

Similarly, we asked participants, how they perceive their Lithuanian language skills. Participants rated their speaking $(\mathrm{M}=4.9$, $\mathrm{SD}=2.22)$ and writing $(\mathrm{M}=4.8, \mathrm{SD}=2.41)$ abilities lower than reading $(\mathrm{M}=5.9, \mathrm{SD}=2.32)$ and listening $(\mathrm{M}=5.5, \mathrm{SD}=2.46)$.

This is consistent with the responses to the next question, in which respondents were asked to choose the most difficult aspect of Lithuanian (participants were allowed to choose more than one answer). As expected, productive skills were perceived as more troublesome (writing: $51.8 \%$, speaking: $50 \%$ ), than receptive (listening: $28.1 \%$, reading: $11.4 \%$ ). The results were in line with the average scores of self-reported skills. 
We were also interested as to whether the above results were related to the linguistic (dis)similarity of the mother tongue of the study participants (MacWhinney 1995). Due to the significant diversity of the respondents, we divided their mother tongues into two groups: fusional (like Lithuanian) and other (non-fusional). It turned out that there were no statistically significant differences between the groups in terms of the perception of difficulties in individual areas of the Lithuanian language. This observation may be related to the fact that vast majority of respondents had no, a prebasic, or a basic level of knowledge of Lithuanian and at this stage practical skills are limited (Ramonaite 2015). Further research into the difficulties in acquiring Lithuanian as a foreign language is needed, e.g. due not only to country of origin but also level of language proficiency, when different skills were developed (pronunciation, advanced grammar), etc. Some studies have already addressed specific topics, such as assignment of natural gender to nouns in Lithuanian (Bružaitè-Liseckienè 2017).

Next, we wanted to investigate whether there were any relationship between motivation and self-reported Lithuanian language skills as well as attitudes towards learning the language. A number of studies have revealed that many factors, including the ones mentioned above, have had an influence on foreign language learning (Gonzales, Lopez 2016; Ushioda 2001, 2008; Williams, Burden, Lanvers 2002; Yuanfang 2009). As stated by Gardner (2005), attitudes towards learning influence and maintain a learner's level of motivation, while motivation must be supported by the ability to successfully learn a foreign language to achieve higher scores.

Table 3 below shows the relationship between the motivational factors and self-reported skills and attitudes towards learning. Spearman's correlation coefficient was used for the data analysis. Results indicate that Lithuanian language motivation factors are more highly correlated with learners' attitude to learning Lithuanian as being satisfying $(\mathrm{r}=.28-.62, \mathrm{p}<.01,2$ tailed $)$ and fun $(\mathrm{r}=.11-.48$, $\mathrm{p}<.01$ [apart F1 and F6, see: table 3], 2 tailed) than easy $(\mathrm{r}=-.06-.16$, 
$\mathrm{p}>.05,2$ tailed). All Lithuanian language skills are positively and significantly correlated with motivation factors concerning selfsatisfaction (F4) and self-efficacy (F5). Speaking, reading and writing are also significantly correlated with factor concerning career enhancement, while two skills (speaking and listening) significantly correlate with the motivation factor concerning cultural integration (F6). Our results confirmed the results of previous research and the importance of learners' attitude and ability on their motivation.

Table 3. Correlation of FLLMQ and Learners' Attitude and Perception of Lithuanian Language Skills

\begin{tabular}{|l|c|c|c|c|c|c|c|}
\hline FLLMQ Factors & $\begin{array}{c}\text { LL is } \\
\text { Easy }\end{array}$ & $\begin{array}{c}\text { LL is } \\
\text { Fun }\end{array}$ & $\begin{array}{c}\text { LL is } \\
\text { Satisfying }\end{array}$ & $\begin{array}{c}\text { Speak- } \\
\text { ing }\end{array}$ & $\begin{array}{c}\text { Read- } \\
\text { ing }\end{array}$ & $\begin{array}{c}\text { Listen- } \\
\text { ing }\end{array}$ & Writing \\
\hline $\begin{array}{l}\text { FI: Career } \\
\text { enhancement }\end{array}$ & .16 & .11 & $.28 * *$ & $.26 *$ & $.21 *$ & .17 & $.19 *$ \\
\hline F2: Global citizenship & -.06 & $.22 * *$ & $.33 * *$ & .09 & .05 & .08 & .02 \\
\hline $\begin{array}{l}\text { F3: Affiliation with } \\
\text { foreigners }\end{array}$ & -.04 & $.39 * *$ & $.44 * *$ & .09 & .1 & .07 & .03 \\
\hline F4: Self-satisfaction & .15 & $.45 * *$ & $.56 * *$ & $.38^{* *}$ & $.35 * *$ & $.26 * *$ & $.32 * *$ \\
\hline F5: Self-efficacy & .13 & $.48^{* *}$ & $.62 * *$ & $.49 * *$ & $.47 * *$ & $.37 * *$ & $.39 * *$ \\
\hline F6: Cultural integration & -.01 & $.21 *$ & $.4 * *$ & $.25 *$ & .17 & $.23 *$ & .04 \\
\hline
\end{tabular}

* Correlation is significant at the 0.05 level (2-tailed).

*** Correlation is significant at the 0.01 level (2-tailed).

\section{Discussion}

The present research has demonstrated that adult learners of Lithuanian as a foreign language are motivated mainly by intrinsic and integrative factors, while the instrumental plays a lesser role. The results are in line with the theoretical framework described at the beginning of this article. The analysis of open-ended questions showed that the specificity of the Lithuanian language, as the "oldest Indo-European language", had a special, autotelic value for the participants. 
An important result of the study is also the observation of variables differentiating the motivational orientation of the participants: whether or not country of origin borders Lithuania, country of origin is or is not in EU, intention or lack thereof to live in Lithuania into future, as well as the willingness or otherwise to continue learning the Lithuanian language and achieve a proficient level in the language. The study also showed significant correlations between motivation and a specific attitude to the Lithuanian language, as well as self-reported language skills, which confirmed the results of previous research. As expected, among all language skills, participants rated their receptive abilities higher than productive skills. They also perceived learning Lithuanian as satisfying and fun, albeit difficult.

Based on the results of the study, further study into Lithuanian language learners' motivation and the role this motivation plays for the desire to integrate into other cultures is recommended. It would be interesting to conduct the research on a larger sample of respondents, search for other variables and conduct a more detailed analysis of the variables already detected in this study. The research results can be used in a practical dimension and provide valuable insights for lecturers.

Our research confirms the hypothesis that foreigners coming to Lithuania to learn the language are more driven by the desire to integrate with Lithuanians and their culture. Similar conclusions have also been drawn by other researchers (Zygmantas 2011; Ramonaite 2019). Integrative motivation is a factor to consider when designing the curriculum of a foreign language course. The program of activities should include contact with Lithuanian culture and natives, which not only facilitates language learning (Strong 2008), but also prevents the consolidation of negative intercultural stereotypes (Sajavaara 2000).

Being aware of these dependencies is especially important considering the fact that people from different countries and groups (age, professional, socio-cultural) are interested in learning Lithuanian; 
something this study uncovered. Such a process is strengthened by globalization and the policy of multilingualism - knowledge of foreign languages is perceived as an asset in career development (Zhang et al. 2020; Hogan-Brun 2017; Cobel-Tokarska 2014).

At the same time, language is inextricably intertwined with culture and influences thinking (Clark 2005). To truly understand another culture, and not simply communicate with its members, you need to learn the culture's language. This allows for mutual learning, leading to the perception of one's own belonging to a wider, sometimes global, community (Reysen, Katzarska-Miller 2018: IX-X). This is in line with the idea of multiculturalism, equal respect for all languages and promoting the discovery of "smaller" languages as well.

\section{REFERENCES}

Al-Ta'ani, Mohammed 2018. Integrative and Instrumental Motivations for Learning English as a University Requirement among Undergraduate Students at Al-Jazeera University/Dubai. - International Journal of Learning and Development 84, 89-105.

Alizadeh, Mitra 2016. The Impact of Motivation on English. - Language Learning 1, 1, 11-15.

Arnold, Jane; H. Douglas Brown 2005. A map of the terrain. - Affect in language learning. Ed. J. Arnold. Cambridge: Cambridge University Press, $1-24$.

Brown, H. Douglas 2007. Principles of Language Learning and Teaching. 5th ed. New York: Pearson Education.

Bružaitè-Liseckienè, Justina 2017. Lietuvių kalbos kaip svetimosios semantiškai motyvuotos daiktavardžių giminès atpažinimo klausimai. - Taikomoji kalbotyra 9, 1-30.

Buivydiené, Vaida; Žukiené, Regina 2006. Lietuvių kalbos kaip svetimosios mokymas(-is) ir sociokultūrinis kontekstas. - Santalka 14, 4, 4-12.

Chomsky, Noam 1988. Language and problems of knowledge. Cambridge, MA: MIT Press.

Clark, Andy 2005. Word, Niche and Super-Niche: How Language Makes Minds Matter More. - Theoria 54, 255-268. 
Richard, Clément; Dörnyei, Zoltán; Noels, Kimberly 1994. Motivation, selfconfidence, and group-cohesion in the foreign language classroom. Language Learning 44, 417-448.

Cobel-Tokarska, Marta 2013. Dlaczego uczymy się języka czeskiego? Sąsiedztwa III RP - Czechy - Zagadnienia Społeczne. Eds. J. Makaro, M. Dębicki. Wrocław: Gajt, 198-215.

Crookes, Graham; Schmidt, Richard W. 1991. Motivation: Reopening the research agenda. - Language Learning 414, 469-512.

Dabašinskienè, Ineta; Čubajevaite, Laura 2009. Acquisition of Case in Lithuanian as L2: Error Analysis. - Eesti Rakenduslingvistika Ühingu aastaraamat 5, 47-65.

Dąbrowska, Anna 2008. Dlaczego cudzoziemcy uczą się języka polskiego? Stare i nowe w nauczaniu JPJO. - Nowe spojrzenie na motywację w dydaktyce języków obcych. Eds. A. Michońska-Stadnik, Z. Wąsik, 47-60.

Deci, Edward; Ryan, Richard M. 1985. Intrinsic Motivation and Self-Determination in Human Behavior. New York: Plenum Press.

Deci, Edward; Ryan, Richard M. 2000. Self-Determination Theory and the Facilitation of Intrinsic Motivation, Social Development, and WellBeing. - American Psychologist 55, 1, 68-78.

Dörnyei, Zoltán 1990. Conceptualizing motivation in foreign language learning. - Language Learning 40, 45-78.

Dörnyei, Zoltán 1994. Motivation and motivating in a foreign language classroom. - The Modern Language Journal 783, 273-284.

Dörnyei, Zoltán 1998. Motivation in second and foreign language learning. - Language Teaching 31, 117-135.

Dörnyei, Zoltán; Ushioda, Ema (Eds.) 2009. Motivation, Language Identity and the L2 Self. Bristol: MPG Books Ltd.

Gardner, Robert C. 1985. Social Psychology and Second Language Learning: The Role of Attitudes and Motivation. London: Edward Arnold.

Gardner, Robert C. 2005. Gardner and Lambert (1959): Fifty years and counting. Paper presented at the Canadian Association of Applied Linguistics. http://publish.uwo.ca/ gardner/ (25.09.2020).

Gardner, Robert C. 2006. Motivation for second language acquisition. https://publish.uwo.ca/ gardner/docs/SPAINTALK.pdf (25.09.2020). 
Gardner, Robert C.; Lambert, Wallace E. 1959. Motivational variables in second language acquisition. - Canadian Journal of Psychology 13, 266-272.

Gardner, Robert C.; Lambert, Wallace E. 1972. Attitudes and motivation: Second language learning. Rowley, MA: Newbury House.

Geben, Kinga; Ramoniene, Meilute 2015. Language use and self-identification: The case of Lithuanian Poles. - Sociolinguistic Studies 9, 2/3, 243-268.

Gonzales, Richard DLC 2010. Motivational Orientation in Foreign Language Learning: The Case of Filipino Foreign Language Learners. - TESOL Journal, 3, 3-28.

Gonzales, Richard DLC; Lopez, Marcos Y. 2016. Foreign language learning motivation questionnaire for Filipinos: Further examination of sixfactor model. Unpublished manuscript, Graduate School, University of Santo Tomas, Manila, Philippines.

Gonzales, Richard DLC; Lopez, Marcos Y. 2017. Examining the Relationship between Foreign Language Learning Motivation and Critical Thinking Motivation: The Case of Filipino Foreign Language Learners. - L2 Selves and Motivations in Asian Contexts. Eds. M. T. Apple, D. Da Silva, T. Fellner. Bristol: Multilingual Matters, 94-118.

Hogan-Brun, Gabrielle; Ozolins, Uldis; Ramonienė, Meilutė; Rannut, Mart 2008. Language Politics and Practices in the Baltic States. - Language Planning and Policy in Europe, vol. 3: The Baltic States, Ireland and Italy. Eds. R. B. Kaplan, R. B. Baldauf Jr. Clevedon, Buffalo, Toronto: Multilingual Matters LTD, 31-192.

Hogan-Brun, Gabrielle; Ramonienè, Meilutė; Grumadienè, Laima 2005. The language situation in Lithuania. - Journal of Baltic Studies 36, 3, 345-370.

Hogan-Brun, Gabrielle 2017. Linguanomics. What is the Market Potential of Multilingualism? London: Bloomsbury Academic.

Klaas-Lang, Birute; Reile, Liis 2019. Miks õppida "väikest keelt"? integratiivne vs. instrumentaalne motivatsioon välisüliópilaste eesti keele õppimisel. - Eesti Rakenduslingvistika Ühingu aastaraamat / Estonian Papers in Applied Linguistics 15, 83-98. 
Klimas, Antanas 1969. The Importance of Lithuanian for Indo-European Linguistics, Lituanus. - Lithuanian Quarterly Journal of Arts and Sciences 15, 3. http://www.lituanus.org/1969/69_3_02.htm (25.09.2020).

Keller, John M. 1983. Motivational design of instruction. - Instructional Theories and Models: An Overview of Their Current Status. Ed. C. M. Reigeluth. New York: Lawrence Erlbaum, 383-434.

Kleinginna, Paul; Kleinginna, Anne 1981. A categorized list of motivation definitions, with suggestions for a consensual definition. - Motivation and Emotion 5, 263-291.

Kowal, Iwona 2019. Motywacja do studiowania filologii szwedzkiej jako filologii rzadkiej. - Języki Obce w Szkole 2, 37-41.

Lankiewicz, Hadrian A. 2010. Foundations of second language acquisition. From theory to language pedagogy. Piła: Państwowa Wyższa Szkoła Zawodowa.

Laizāne, Inga 2017. Acquisition of Latvian as a Foreign Language in Latvia: Development and Trends. - Rural Environment. Education. Personality. (REEP): Proceedings of the 10th International Scientific Conference 10, 116-120.

Laizāne, Inga 2018. The Understanding of the Concepts of First Language, Second Language and Foreign Language Outside of Latvia. - Rural Environment. Education. Personality (REEP). Proceedings of the International Scientific Conference 11, 81-87.

Likert, Rensis 1932. A technique for the measurement of attitudes. - Archives of Psychology 22, 140, 1-55.

MacWhinney, Brian 1995. Language-Specific Prediction in Foreign Language Learning. - Language Testing 12, 3, 292-320.

Nelis, Liis; Miljan, Merilin 2016. Acquisition of Motion in L2 Estonian. Eesti Rakenduslingvistika Ühingu aastaraamat 12, 161-185.

Oxford, Rebecca; Ehrman, Madeline E. 1992. Second language research on individual differences. - Annual Review of Applied Linguistics 13, 188-205.

Ramonaitė, Jogilè T. 2015. Kaip lietuviškai šneka užsieniečiai? Lietuvių kaip antrosios kalbos veiksmažodžio ịsisavinimas. - Baltistica 50, 2, 295-330.

Ramonaité, Jogilè T. 2017a. Bendratis lietuvių kaip antrojoje kalboje: Infinitive in Lithuanian as a second language. - Baltistica 52, 1, 81-104. 
Ramonaitè, Jogilè T. 2017b. Ką pasako tokios užsieniečių sudaromos formos kaip valgu ar žinèjau? - Lietuvių Kalba 11, 1-25.

Ramonaité, Jogilè T. 2019. Do I need want to speak? Foreigners in a "small" language country. - Journal of Baltic Studies 51, 1, 35-50.

Ramonienè, Meilutė 2006. Teaching Lithuanian as a second/foreign language: current practices. - Eesti Rakenduslingvistika Ühingu aastaraamat 2, 219-230.

Reysen, Stephen; Katzarska-Miller, Iva 2018. The psychology of global citizenship: A review of theory and research. Lanham: Rowman \& Littlefield.

Richards, Jack C.; Schmidt, Richard 2010. Longman Dictionary of Language Teaching and Applied Linguistics. 4th edn. London: Longman.

Saheb, Véronique 2014. Motivation in English as a Foreign Language Learning: A study of motivation toward English language learning in Stockholm's upper secondary schools for adults. KOMVUX. University of Halmstad, School of Humanities. https://www.diva-portal.org/smash/get/ diva2:782288/FULLTEXT01.pdf (25.09.2020).

Sajavaara, Anu 2000. Virkamies ja vieraat kielet virkamiesten kielikoulutuksen arviointihankkeen loppuraportti (The civil servant and foreign languages: final report of language needs assessment). Finland: Centre for Applied Language Studies. University of Jyväskylä.

Sheldon, Kennon M.; Ryan, Richard M.; Rawsthorne, Laird; Ilardi, Barbara 1997. Trait self and true self: Cross-role variation in the Big Five traits and its relations with authenticity and subjective well-being. - Journal of Personality and Social Psychology 73, 1380-1393.

Stanulewicz, Danuta 2008. Dlaczego Polacy uczą się języka japońskiego? Między fascynacją a praktycyzmem. - Nowe spojrzenie na motywację dydaktyce języków obcych. Eds. A. Michońska-Stadnik, Z. Wąsik, 137145.

Strong, Dina 2008. Erasmus students' language learning experiences through the prism of SLA theories. - Žmogus kalbos erdveje 5. Eds. D. Balšaitytè et al. Kaunas: Vilnius University, 546-553.

Szałek, Marek 1992. Sposoby podnoszenia motywacji na lekcjach języka obcego. Poznań: Wydawnictwo UAM.

Šalme, Arvils 2011. Latviešu valodas kā svešvalodas apguves pamatjautājumi. Rīga: Latviešu valodas aǵentūra. 
Ushioda, Ema 2001. Language learning at university: Exploring the role of motivational thinking. - Motivation and second language acquisition. Eds. Z. Dörnyei; R. Schmidth. Honolulu, HI: University of Hawai'i Press, 93-125.

Ushioda, Ema 2008. Motivation and good language learners. - Lessons from good language learners. Ed. C. Griffiths. Cambridge, England: Cambridge University Press, 19-34.

Ushioda, Ema; Dörnyei, Zoltán 2017. Beyond Global English: Motivation to Learn Languages in a Multicultural World: Introduction to the Special Issue. - The Modern Language Journal 101, 3, 451-454.

Ur, Penny 1996. A course in language teaching. Practice and Theory. Cambridge: Cambridge University Press.

Vihalemm, Triin; Hogan-Brun, Gabrielle 2013. Language policies and practices across the Baltic. - European Journal of Applied Linguistics 1, 1, $55-82$.

Vilkienė, Loreta; Vilkaitè-Lozdienė, Laura; Bružaitè-Liseckienė, Justina 2019. Lietuvių kalba Vilniaus lietuviškose, lenkiškose ir rusiškose gimnazijose: mokejjimo kokybè, kalbinès nuostatos ir motyvacija. Vilnius: Vilniaus Universiteto Leidykla.

Williams, Marion; Burden, Robert; Lanvers, Ursula 2002. French is the language of love and staff: Student perceptions of issues related to motivation in learning a foreign language. - British Educational Research Journal 28, 4, 503-528.

Woolfolk, Anita 2013. Educational Psychology. Upper Saddle River, New Jersey: Pearson.

Yu, Baohua; Watkins, David A. 2008. Motivational and cultural correlates of second language acquisition: An investigation of international students in the universities of the People's Republic of China. - Australian Review of Applied Linguistics 312, 1-17.

Yuanfang, Yu 2009. A study of foreign language learning motivation and achievement: From a perspective of sociocultural theory. - CELEA Journal 32, 3, 87-97.

Zakarauskaité, Eglè 2006. Lietuvių kalbos kaip svetimosios daiktavardžio morfologijos İsisavinimas (Italès Atvejis). M.A. thesis, Vilnius University. 
Zhang, Huiyu; Dai, Ying; Wang, Yingchong 2020. Motivation and Second Foreign Language Proficiency: The Mediating Role of Foreign Language Enjoyment. - Sustainability 12, 1302.

Zygmantas, Janete 2011. Adult newcomers' difficulties in learning Lithuanian: an ethnographic case study. Vilnius: unpublished doctoral dissertation.

Jakub Kubś is working in Uniwersytet Wrocławski, his research interests are postcolonial theory and colonial narratives in the $\mathrm{XVI}$ c. jantar1991@gmail.com

Aleksandra Michałowska-Kubś is working in Uniwersytet Wrocławski, her research is focused on cultural scenarios and the image of death in new media. a.michalowska.kubs@gmail.com 


\section{LEEDU KEELE ÕPPIMISE MOTIVATSIOON VÄLISMAALASTE SEAS}

Artikkel käsitleb Leetu saabuvate täiskasvanute motivatsiooni õppida leedu keelt võõrkeelena. Arutatakse väikeste keelte õppimise motivatsioonilist tausta. Leedu keel, mida räägib kogu maailmas umbes 3,5 miljonit inimest, on näide võõrkeele õppijate vähem populaarsest valikust. Kuid iseseisvuse taastamine 1990. aastal ja ühinemine Euroopa Liiduga 2004. aastal lõid uued võimalused leedu keele kui võõrkeele õpetamiseks. Selles töös soovisime uurida motivatsioonitegureid, mis motiveerivad välismaiseid täiskasvanuid leedu keelt õppima. Teoreetiline raamistik põhines Gardneri ja Lamberti (1972) ning Ryani ja Deci (1985) motivatsiooniteooriatel. Peamine uurimistööks kasutatud vahend oli võõrkeeleõppe motivatsiooni küsimustik (Gonzales, Lopez 2015). Viisime läbi kvantitatiivse uuringu, mis põhines 114 leedu keele kursustel osalenud vastajal. Tulemused näitavad, et leedu keele õppimine on tihedalt seotud pigem sisemise ja integreeriva kui välise ja instrumentaalse motivatsiooniga, samas kui õpilased hindasid ka leedu keele autoteelist väärtust. See kinnitab, et väikeste keelte õppimine nõuab erilist motivatsiooni ja et instrumentaalne tegur mängib vähem rolli. Selles artiklis arutatakse kõigepealt, kuidas töötati välja võõrkeele õppimise motivatsiooniteooriad. Seejärel esitatakse Leedu sotsiolingvistiline kontekst koos lühikeste märkidega selle omaduste kohta võrreldes teiste Balti riikidega. Seejärel esitatakse uuringute protseduurid ja tulemused. Artikli lõpetab lühike arutelu, mis toob tulemused laiemasse konteksti.

Võtmesõnad: motivatsioon, leedu keel, „väikesed“keeled, võõrkeel, keeleõpe 